\title{
p60-S6K1 REPRESENTS A NOVEL KINASE ACTIVE ISOFORM WITH THE MODE OF REGULATION DISTINCT FROM p70/p85-S6K1 ISOFORMS
}

\author{
I. V. ZAIETS, V. V. HOLIAR, A. S. SIVCHENKO, \\ V. V. SMIALKOVSKA, V. V. FILONENKO \\ Institute of Molecular Biology and Genetics, \\ National Academy of Sciences of Ukraine, Kyiv; \\ e-mail: filonenko@imbg.org.ua
}

Received: 13 March 2019; Accepted: 17 May 2019

The phosphatidylinositol-3-kinase (PI3K)/mechanistic target of rapamycin complex 1 (mTORC1) signaling pathway controls plenty of cellular functions regulating phosphorylation one of its mediators ribosomal protein S6 kinase 1 (S6K1). Alternative translation of the common S6K1 transcript can generate three protein kinase isoforms, including p85-S6K1, p70-S6K1 and p60-S6K1. The catalytic activity of S6K1 is modulated by mitogens and growth factors via phosphorylation at three critical sites such as the activation loop (T-loop site), turn motif (TM site), and hydrophobic motif (HM site). Both members of the PI3K/mTORC1 pathway, PDK1 and mTORC1, directly phosphorylate the T-loop site and HM site, respectively. Indeed, most studies aimed at elucidating S6K1 regulation have focused on p70- and p85-S6K1. Meanwhile, however, the activity of p60-S6K1 and its regulation have not been elucidated so far. To test whether p60-S6K1 was an active kinase isoform that was regulated similar to p70/p85-S6K1, we employed previously generated p85\%/p70-/ p60 HEK-293 cells. First, an in vitro kinase assay confirmed the ability of p60-S6K1 to phosphorylate ribosomal protein S6 (rpS6), a well-known S6K1 substrate. Next, analysis of p60-S6K1 phosphorylation under different cell growth conditions showed that p60-S6K1 does not have detectable levels of phosphorylation at PDK1- and mTORC1-regulated sites, yet this isoform undergoes phosphorylation at the TM site. Finally, we found that activity of p60-S6K1 was not sensitive to mitogenic stimulation and cell treatment by potent inhibitor of the PI3K1/mTORC1-dependent signaling pathway rapamycin suggesting the existence of a PI3K/ mTORC1-independent mechanism of p60-S6K1 regulation in HEK-293. The data of the current study suggest that the p60-S6K1 isoform possesses intrinsic kinase activity that is independent of PI3K/mTORC1 signaling regulation in HEK-293 cells. What is more, modulation of p60-S6K1 activity via the PI3K/mTORC1 signaling pathway seems to be cell-type specific, since the p60-S6K1 isoform undergoes PDK1-and mTORC1-mediated phosphorylation in breast cancer cell line MCF-7.

Keywords: p60-S6 kinase 1 (p60-S6K1), PI3K/mTORC1 signaling pathway, kinase activity, regulation by protein phosphorylation.

$\mathrm{R}$ ibosomal protein S6 kinase 1 (S6K1) controls a number of cellular processes, including protein synthesis, lipid metabolism, cell growth, proliferation and migration, through its kinase activity towards plenty of downstream mediators. The S6K1 gene, referred to as RPS6KB1 in humans, encodes two major isoforms, p70-S6K1 and p85-S6K1 that differs by 23aa at N-terminus, which promote all mentioned cellular functions [1, 2].
Diverse environmental cues (i.e., serum, epidermal growth factor, insulin-like growth factor/ insulin, and phorbol esters) activate p70/p85 S6K1, mainly via the PI3K/mTORC1 signaling pathway. Signaling by growth factors and mitogens initiates phosphorylation of S6K1 on at least eight sites, where three of them, T229/T252, S371/S394 and T389/T412, are critical for p70/p85-S6K1 kinase activity. Regulation of T229 and T389 occurs via

(C) 2019 Zaiets I. V. et al. This is an open-access article distributed under the terms of the Creative Commons Attribution License, which permits unrestricted use, distribution, and reproduction in any medium, provided the original author and source are credited. 
PDK1- and mTORC1-dependent phosphorylation, respectively. In response to growth factors and mitogens co-ordinate phosphorylation of both sites leads to complete S6K1 activation. Abnormal S6K1 gene/ protein expression and function have been shown to promote development and progression of cancer, diabetes, obesity, and several other pathologies [1-4].

In addition to the well-studied p70- and p85S6K1 isoforms, there is evidence that the S6K1 gene encodes another isoform, referred to as p60-S6K1 [5]. However, our knowledge about p60-S6K1 expression, regulation and activity remains quite limited. It has been suggested that p60-S6K1 originates from an alternative translation event $[5,6]$ and represents the N-terminally truncated $\mathrm{S} 6 \mathrm{~K} 1$ isoform (53 amino acids from the N-terminus of p85-S6K1, $\triangle \mathrm{N} 53-\mathrm{p} 85$ ) lacking the mTORC1 binding site, called the TOS motif [5]. Although p60-S6K1 does not possess the TOS motif, it was reported in [5] that the S6K1 isoform is modulated by phosphorylation at the mTORC1-regulated site (T359 in p60-S6K1) in MCF-7 cells, as well as it is subjected to S371 (S341 in p60-S6K1) and T421/S424 (T391/S394 in p60-S6K1) phosphorylation similar to the major p70-S6K1 isoforms in the same cells. Nevertheless, analysis of p60-S6K1 phosphorylation in that study was limited and did not include identification of p60S6K1 phosphorylation at the PDK1-regulated T229 site (T199 in p60-S6K1). Whether the p60-S6K1 isoform possesses kinase activity remains a pending question. Although, several S6K1 structure-function studies demonstrated that different N-terminally truncated S6K1 mutants reminding p60-S6K1 displayed low kinase activity towards ribosomal protein S6 in vitro [7, 8]. However, these data should be interpreted with caution since all tested S6K1 mutants either did not correspond completely to the p60-S6K1 N-terminal amino acid sequence or were epitope-tagged from the $\mathrm{N}$-terminus.

Recently, applying the CRISPR/Cas9 approach, we generated HEK-293 cells with knockout of p70and p85-S6K1 (p85\%/p70//p60+HEK-293) allowing the cells to exclusively express the p60-S6K1 isoform [6]. Expression of p60-S6K1 in these cells was shown to rescue a rate of cell proliferation and migration as compared to HEK-293 with knockout of all three isoforms (p85\%/p70\%/p60-HEK-293). Results of the study emphasized a possible role of p60-S6K1 in the modulation of cell proliferation and motility in HEK-293, thus drawing our attention to the nature of p60-S6K1 action and its regulation in the cell.
In this study, we utilized the p85\%/p70\% p60+HEK-293 cells to examine the ability of p60S6K1 to catalyze the transfer of a phosphate group to ribosomal protein S6 (rpS6), a known S6K1 substrate, in vitro. By employing an in vitro kinase assay, we have determined that the p60-S6K1 isoform possesses kinase activity similarly to the major p70/p85-S6K1 kinase. Next, we estimated a phosphorylation status of $\mathrm{p} 60-\mathrm{S} 6 \mathrm{~K} 1$ in the $\mathrm{p} 85 \% \mathrm{p} 70 \%$ p60 ${ }^{+}$HEK-293 cells under different growth conditions. Analysis of p60-S6K1 phosphorylation has shown that p60-S6K1 does not undergo phosphorylation at mTORC1- and PDK1-regulated sites in $\mathrm{p} 85 \% / \mathrm{p} 70^{-} / \mathrm{p} 60^{+} \mathrm{HEK}-293$, thus implying the existence of the mechanism of p60-S6K1 activity regulation other than that for p70/p85-S6K1. Indeed, supporting this hypothesis, we found that the activity of p60-S6K1 is not regulated by mitogenic stimuli and is not responsive to cell treatment with potent inhibitor of PI3K1/mTORC1-dependent signaling pathway rapamycin. Consistent with the data of Kim et al. [5] our study also revealed that modulation of p60-S6K1 activity seems to be cell-type specific, since the p60-S6K1 isoform undergoes PDK1- and mTORC1mediated phosphorylation in breast cancer cell line MCF-7. Taken together, our data suggest that p60S6K1 represents a kinase active isoform that can be modulated by the PI3K/mTORC1 signaling pathway depending on a cell type. Future work will be required, however, to define the function of p60-S6K1 and the mechanisms underlying its regulation in the cell.

\section{Materials and Methods}

Cell culture and transfection. HEK-293 and p85 $/ \mathrm{p} 70^{-} / \mathrm{p} 60^{+} \mathrm{HEK}-293$ cells were maintained in Dulbecco's Modified Eagle's Medium (DMEM) (GIBCO) containing 10\% fetal bovine serum (FBS) (GIBCO), 100 units/ml penicillin, and $100 \mu \mathrm{g} / \mathrm{ml}$ streptomycin. Development of cell clones modified with CRISPR/Cas9 targeting p85- and p70-S6K1 was described in [6]. For experiments involving serum stimulation, rapamycin and LY294002 inhibition, cells were washed twice with phosphatebuffered saline (PBS) and after that serum-starved for $24 \mathrm{~h}$ in DMEM deprived of serum. Then the cells were either incubated with 20\% FBS for $1 \mathrm{~h}$ or treated with $50 \mu \mathrm{M}$ LY294002 (LC Laboratories) or $20 \mathrm{nM}$ rapamycin (CST) for $30 \mathrm{~min}$ with subsequent serum stimulation for $1 \mathrm{~h}$. 
Plasmids and recombinant proteins. Generation of the pSpCas9(BB)-2A-Puro (PX459) V2.0 DNA vector containing anti-p85/p70 was described previously [6]. Purified recombinant 6X-His-tagged rpS6 was a gift from Garifulin O. M. (Department of cell signalling, IMBG of NASU, Kyiv, Ukraine).

Cell lysis and Western blot analysis. All cells were rinsed once with PBS and lysed in ice-cold cell lysis buffer containing $25 \mathrm{mM}$ Tris- $\mathrm{HCl}, \mathrm{pH} 7.5$, $150 \mathrm{mM} \mathrm{NaCl}, 1 \mathrm{mM}$ EDTA, $0.5 \%$ Triton X-100, $5 \%$ glycerol, $1 \mathrm{mM} \mathrm{Na}_{3} \mathrm{VO}_{4}, 2.5 \mathrm{mM}$ Na pyrophosphate, $1 \mathrm{mM} \beta$-glycerophosphate supplemented with a cOmplete EDTA-free protease inhibitor cocktail tablet (Roche) and phosphatase inhibitors (SigmaAldrich). After incubation of scraped cell lysates for $20 \mathrm{~min}$ at $4{ }^{\circ} \mathrm{C}$ the lysates were cleared by centrifugation at $12,000 \mathrm{x} \mathrm{g}$ for $10 \mathrm{~min}$ at $4{ }^{\circ} \mathrm{C}$. Coomassie Protein Assay Reagent (Thermo Fisher Scientific) was applied to measure protein concentration in soluble fractions of whole-cell lysates and samples containing equal amount of protein were resolved by $10 \%$ SDS-PAGE. The protein samples subjected to SDS-PAGE were transferred to a polyvinylidene difluoride (PVDF) membrane (Immobilon ${ }^{\circledR}-\mathrm{P}$, Millipore). The membrane was probed with a specific primary antibody followed by incubation with an appropriate secondary antibody diluted $1: 10000$. Thereafter, a signal was developed with enhanced chemiluminescence (GE Healthcare). Primary antibodies used in this study were diluted according to the manufacturer's instructions and obtained from: C-terminal S6K1 (generated as described in [9]) diluted $1: 2500(0.4 \mu \mathrm{g} / \mathrm{ml})$, phospho-p70S6K1 (Thr389) (\#9234, CST), phospho-p70-S6K1 (Ser371) (\#9208, CST), phospho-p70-S6K1 (Thr229) (MAB8964, R\&D Systems), phospho-p70-S6K1 (Ser421/Thr424) [\#9204, CST], phospho-rpS6 (Ser240/244) (\#5364, CST), 6x-His Tag (clone HIS. H8, \#MA1-21315, Thermo Fisher Scientific), $\beta$-actin (clone AC-15, \#A5441, Sigma-Aldrich). Secondary anti-mouse and anti-rabbit antibodies were obtained from Jackson ImmunoResearch. The secondary antirabbit light chain specific antibody was purchased from Millipore.

Immunoprecipitation and kinase assay. Wholecell lysates from 6 x 106 cells were prepared as described above in the section "Cell lysis and Western blot". For immunoprecipitation of S6K1 $10 \mu \mathrm{l}$ of swollen protein $\mathrm{G}$ agarose equilibrated in cell lysis buffer were mixed with $2.5 \mu \mathrm{g}$ of polyclonal antiS6K1 (against the C-terminus) and the mixture was incubated for $1 \mathrm{~h}$ at room temperature with shaking. During the next step of immunoprecipitation, the antibodies attached to protein $\mathrm{G}$ agarose were incubated with the whole-cell lysates overnight at $4{ }^{\circ} \mathrm{C}$ with shaking. For negative controls equilibrated protein $\mathrm{G}$ agarose was directly incubated with the cell lysates avoiding the step of antibody addition. Immunoprecipitates and $G$ agarose as the negative control were washed 3 times with cell lysis buffer followed by washing with kinase buffer $(25 \mathrm{mM}$ Tris-HCl, $\mathrm{pH}$ 7.5, $10 \mathrm{mM} \mathrm{MgCl}_{2}, 2 \mathrm{mM}$ DTT, $0.1 \mathrm{mM} \mathrm{Na}_{3} \mathrm{VO}_{4}$, $5 \mathrm{mM} \beta$-glycerophosphate). After the washing step samples were incubated with $6 X$-His-rpS6 in the presence of $1 \mathrm{mM}$ ATP in reaction buffer containing $250 \mathrm{mM}$ Tris-HCl, pH 7.5, $100 \mathrm{mM} \mathrm{MgCl}, 20 \mathrm{mM}$ DTT, $1 \mathrm{mM} \mathrm{Na}_{3} \mathrm{VO}_{4}, 50 \mathrm{mM} \beta$-glycerophosphate. After 30 min incubation at $37^{\circ} \mathrm{C}$, reactions were terminated by adding SDS sample buffer ( $2 \mathrm{X}$ final relative concentration) and subjected to western blot analysis as described above.

\section{Results and Discussions}

We recently reported that HEK-293 cells expressing only the p60 isoform (p85\%p70\% p60 HEK-293 cells) display higher rates of cell proliferation and cell migration compared to HEK-293 with knockout of all isoforms [6]. These observations suggest that p60-S6K1 could be involved in the control of cell proliferation and motility. A possible role of p60-S6K1 in mediating cellular functions raises some questions of the nature of p60-S6K1 intrinsic activity, through which it could exert its cellular effects, as well as modes of regulation of this activity. To date, however, mechanisms of p60-S6K1 action and regulation have not been elucidated. Thus, the present study was focused on investigating these matters.

Since p60-S6K1 comprises a kinase domain within its amino acid sequence, it could possess catalytic activity similar to p70-S6K1. To determine whether endogenous p60-S6K1 is catalytically active we immunoprecipitated the p60-S6K1 protein from $\mathrm{p} 85 \% / \mathrm{p} 70^{-} / \mathrm{p} 60^{+} \mathrm{HEK}-293$ cells displaying elevated p60-S6K1 expression level [6] and performed an in vitro kinase assay using a typical S6K1 substrate, ribosomal protein S6 (rpS6). Results demonstrated that immunoprecipitated p60-S6K1 phosphorylates in vitro rpS6 at Ser-240/244 (Fig. 1). According to these results, however, p60-S6K1 kinase activity towards rpS6 is somewhat lower compared to p70/ p85-S6K1. 
$A$

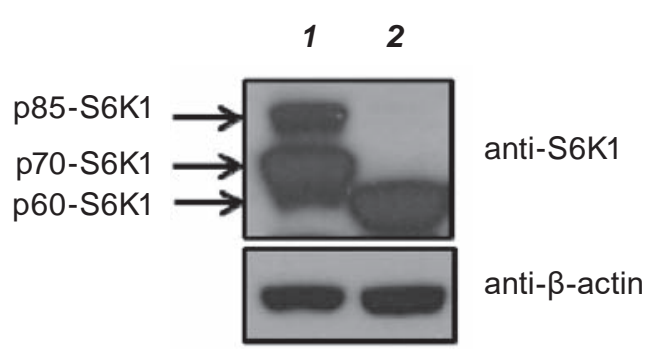

B

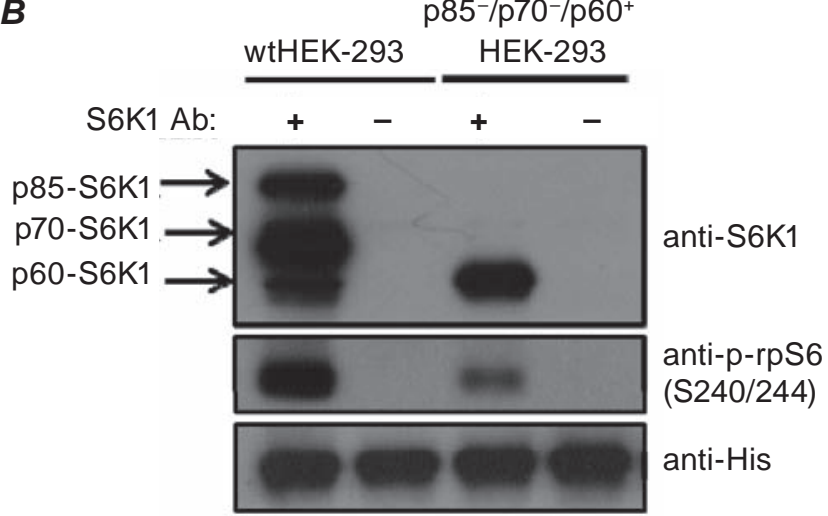

Fig. 1. p60-S6K1 represents a kinase active isoform of $S 6 K 1$ as revealed by the in vitro kinase assay. $A-H E K-$ 293 cells were modified by the anti-p85/p70 gRNA/Cas9 system. A clone expressing exclusively p60-S6K1 was selected and analyzed by western blot. Cell lysates from wtHEK-293 and p85-/p70-/p60 ${ }^{+} H E K-293$ were immunoblotted with C-terminal S6K1 antibodies and $\beta$-actin antibodies used as a loading control. 1 - wildtype HEK-293; 2 - p85 $/ p 70^{-} / p 60^{+} H E K-293$. B - S6K1 isoforms were immunoprecipitated from the indicated cells by the polyclonal C-terminal S6K1 antibodies and kinase activity of immunoprecipitates was determined using 6X-His-tagged rpS6 as a substrate. Analysis of kinase reaction was performed using western blot. S6K1 - S6 kinase 1; rpS6 - ribosomal protein S6; His - histidine

It should be noted, however, that there have been several S6K1 mutagenesis studies which used a number of S6K1 mutants resembling p60-S6K1 to define a mechanism of p70/p85 activation. In one study [7] a small deletion of the p85-S6K1 Nterminus, $\Delta 58$-p85, resulted in the kinase inactive S6K1 mutant, whereas authors of the other report [8] employed an N-terminal deletion of p70-S6K1, $\Delta 53-\mathrm{p} 85$, and the generated mutant exhibited significantly reduced kinase activity relative to the wildtype protein. Yet the S6K1 mutant used in [7] represented a deleted form of p60-S6K1, $\Delta 58$-p85, lacking five extreme N-terminal amino acids. Although an amino acid sequence of the S6K1 mutant generated in [8] showed complete resemblance to p60-S6K1, it was amino-terminally tagged with the HA-epitope, which complicates interpretation of the data. In addition, both studies employed cell models different from that used in the current study, assuming that p60-S6K1 could differently be regulated in a distinct cell type. This may account for why there has been a discrepancy between the results obtained by these authors and the data of our study.

To date, evidence shows that Thr229 (T-loop site, Thr199 in p60-S6K1), Ser371 (TM site, Ser341 in p60-S6K1) and Thr389 (HM site, Thr359 in p60S6K1) represent the main sites phosphorylation of which is crucial for p70-S6K1 activity of [10-18]. Direct regulators of Thr229 and Thr389 include PDK1 [10-11] and mTORC1 [14, 15, 17], respectively, which are components of the PI3K/mTORC1 signaling axis, whereas the identity of Ser371 kinase remains unclear [18]. In the meantime, phosphorylation of Ser411, Ser418, Thr421 and Ser424 (Ser381, Ser388, Thr391 and Ser394 in p60-S6K1) reflects an early step in p70-S6K1 activation in response to growth factors and mitogens [19, 20], and, likewise Ser371, physiological kinases for these sites remain to be identified. These four proline-directed sites lie in the C-terminal autoinhibitory domain that interacts with the N-terminal domain in the inactive state [21, 22]. Nevertheless, phosphorylation of S6K1 at these sites is not critical for kinase activity, even if it contributes to the active state [17, 23, 24].

After revealing p60-S6K1 kinase activity, we concentrated on studying its regulation via phosphorylation at above-described sites to find out whether the p60-S6K1 isoform undergoes the similar mode of phosphorylation as the p70- and p85S6K1 isoforms in response to extracellular stimuli. Surprisingly, analysis of p60-S6K1 phosphorylation at T-loop and HM sites by immunoblotting showed that no detectable level of Thr229 (Thr199) and Thr389 (Thr359) phosphorylation was observed in the $\mathrm{p} 85^{\circ} / \mathrm{p} 70^{-} / \mathrm{p} 60^{+} \mathrm{HEK}-293$ cells at different growth conditions (Fig. 2, A) and at different time points after serum stimulation (Fig. 3). This suggests that p60-S6K1 could not be subjected to Thr199 and Thr359 site-specific phosphorylation in these cells. Hence, kinase activity of p60-S6K1 in p85\%p70\% 
$\boldsymbol{A}$

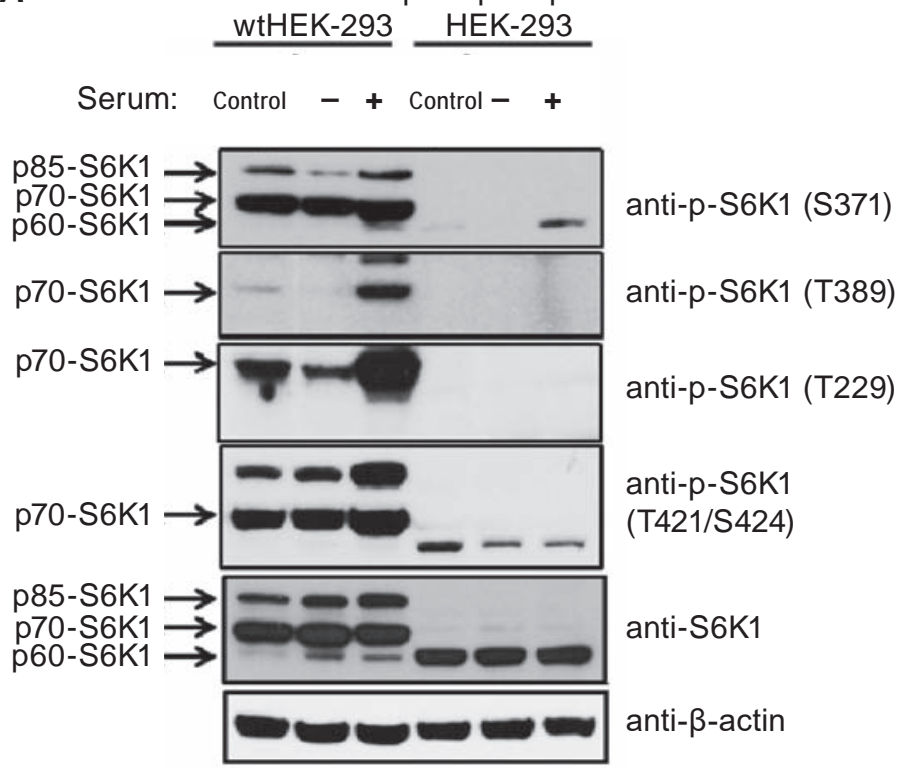

B
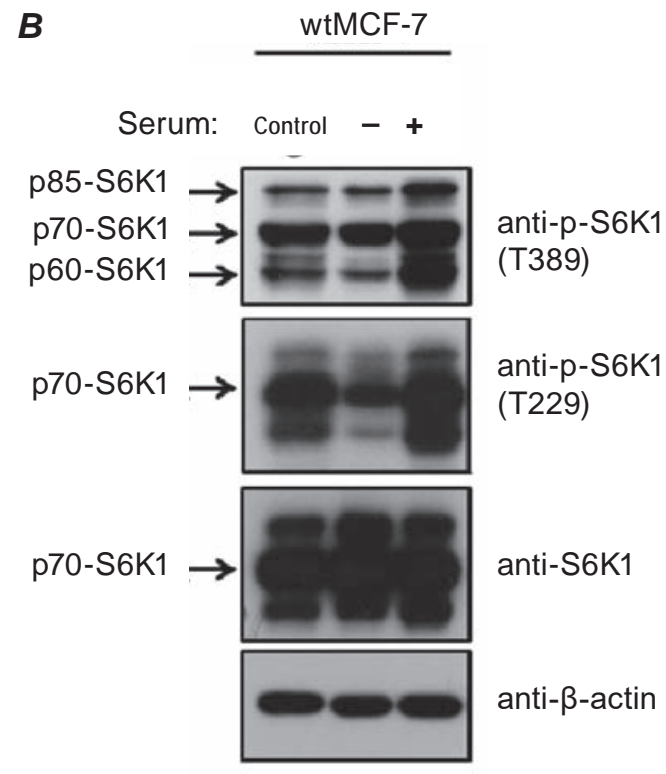

Fig. 2. Distinct phosphorylation pattern of the p60-S6K1 isoform in different cell lines. Wild-type HEK-293 (A), p85\%/p70 / $1060^{+} H E K-293$ (A) and wild-type MCF-7 cells (B) were subjected to a starvation in serum-depleted DMEM for $24 \mathrm{~h}$. Afterwards the cells were stimulated with 20\% FBS for $1 \mathrm{~h}$. Cell lysates were analyzed by western blot using the indicated antibodies. $\beta$-actin was used as a loading control

p60+HEK-293 could be regulated by mechanisms and/or signaling pathways other than that of p70S6K1. In contrast, results reported by Kim et al. [5] indicate that p60-S6K1 is phosphorylated at the Thr389 site in the breast cancer cell line MCF-7. Such controversy may arise from the usage of different cell models for the analysis of Thr-389 phosphorylation levels. Considering this fact, p60-S6K1 could display different modes of regulation of its activity depending on a cell type-specific context. Thus we applied MCF-7 cells to investigate a phosphorylation status of p60-S6K1. Indeed, as our results demonstrate, in these cells p60-S6K1 is highly phosphorylated at PDK1- and mTORC1-regulated sites (Fig. 2, $B$ ), which is consistent with the results shown in [5].

Although Ser371-specific kinase has not been identified so far, this phosphorylation event is also critical for p70-S6K1 kinase activity as indicated by mutagenesis studies [18]. Despite levels of p60-S6K1 phosphorylation at Thr229 (Thr199) and Thr389 (Thr359) was not observed, p60-S6K1 displayed detectable levels of Ser371 (Ser341) phosphorylation (Fig. 2, 3). In this study, we also assessed status of p60-S6K1 phosphorylation at C-terminal sites, including Thr-421/Ser-424 (Thr391/Ser394). Although phosphorylation at these sites was observed (Fig 2), dynamics of this event induced by serum was sig- nificantly distinct from that of p70/p85-S6K1, unlike p60-S6K1 phosphorylation at the Ser341 site (Fig. 3). Thus phosphorylation of p60-S6K1 at Thr421/Ser-424 (Thr391/Ser394) displayed clear peaks of increased and decreased phosphorylation after 5-20 min and $1 \mathrm{~h}$ after serum stimulation correspondently. In contrast, p70-S6K1 did not display clearly defined peaks of up and down phosphorylation at Thr-421/Ser-424. Although, a slight increase in p70-S6K1 (Thr421/Ser424) phosphorylation was observed. Interestingly, prolonged exposure to growth factors induced elevated levels of p60-S6K1 expression starting from $3 \mathrm{~h}$ of serum stimulation in the $\mathrm{p} 85 \% / \mathrm{p} 70^{-} / \mathrm{p} 60^{+} \mathrm{HEK}-293$ cells and $2 \mathrm{~h}$ of serum stimulation in wild-type counterparts.

As current evidence suggests, the activation status of p70/p85-S6K1 is controlled by the PI3K1/ mTORC1 signaling pathway in response to growth factor and mitogenic stimuli [1]. The absence of Thr229 (Thr199) and Thr389 (Thr359) phosphorylation in p60-S6K1 that is a most critical for p70/85-S6K1 led to an assumption that regulation of p60-S6K1 activity occurs in PI3K/mTORC1independent manner at least in HEK-293. To test if PI3K1/mTORC1-dependent signaling regulates the activity of p60-S6K1, we introduced cell treatment with mTOR-specific inhibitor rapamycin. The $\mathrm{p} 85 \%$ 
$\boldsymbol{A}$

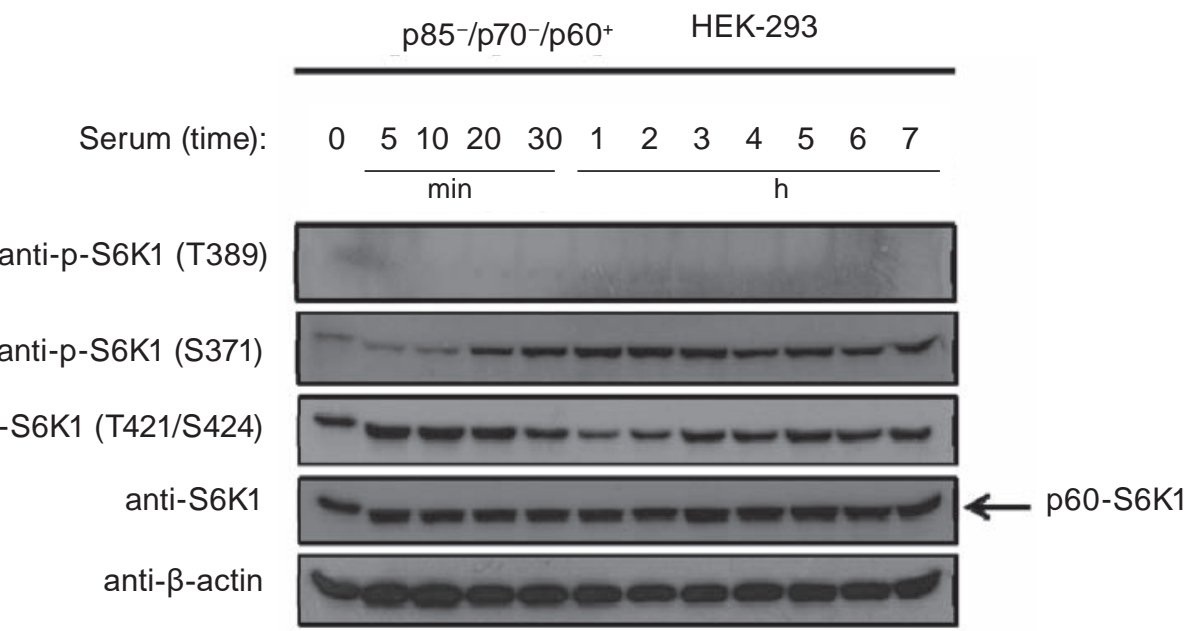

B

wtHEK-293

Serum (time):
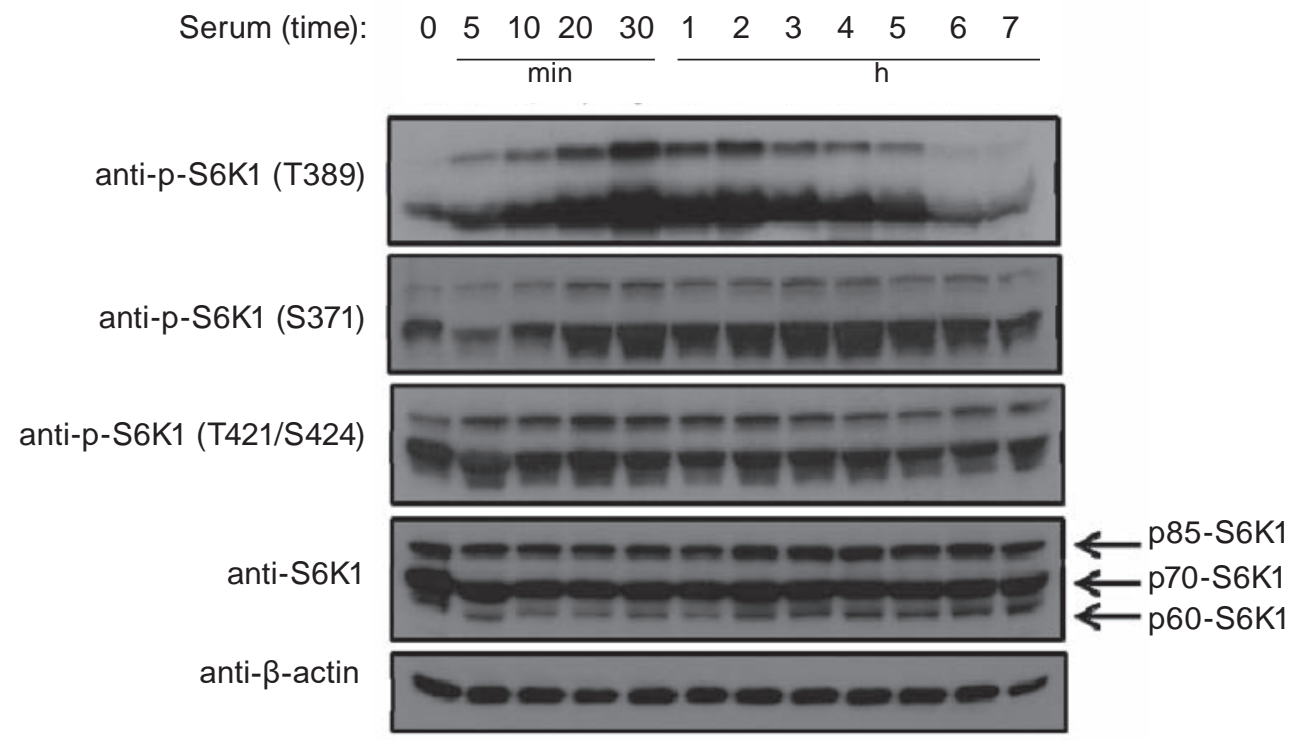

Fig 3. The p60-S6K1 isoform reveals different time-dependent dynamics of phosphorylation in HEK-293 cells at S371 and T421/S424, under conditions of growth factor stimulation. wtHEK-293 and p85 $/ \mathrm{p} 70^{-} / \mathrm{p} 60^{+} \mathrm{HEK}-293$ cells were serum-starved for $24 \mathrm{~h}$ and then stimulated with 20\% FBS for indicated periods of time. After incubation with serum, the cells were lysed and protein fractions were resolved by SDS-PAGE with subsequent blotting against the indicated antibodies. To confirm equal loading of protein samples, antibodies against $\beta$-actin were applied. All numbers indicating phosphorylation sites correspond to $p 70-S 6 K 1$

p70 $/ \mathrm{p} 60^{+}$HEK-293 cells were serum-starved and then incubated in the presence of rapamycin followed by serum stimulation. After that, p60-S6K1 was immunoprecipitated from whole-cell lysates and its activity was analyzed by an in vitro kinase assay (Fig. 4). The obtained data revealed that p60-S6K1 represents rapamycin-insensitive kinase, as well as this isoform is insensitive to growth factor starvation and stimulation. These findings indicate that PI3K/mTORC1-dependent signaling indeed does not modulate p60-S6K1 kinase activity in HEK293 cells. On the contrary, inhibition of the PI3K/ mTORC1 pathway in the p85\%/p70\%/p60 HEK-293 cells caused complete suppression of endogenous rpS6 phosphorylation at Ser-240/244, similar to wild-type HEK-293 cells (Fig. 5). This could occur due to distinct substrate specificities for p60-S6K1 and p70/p85-S6K1, implying that rpS6 might not represent a physiological substrate for the p60-S6K1 kinase-active isoform. 


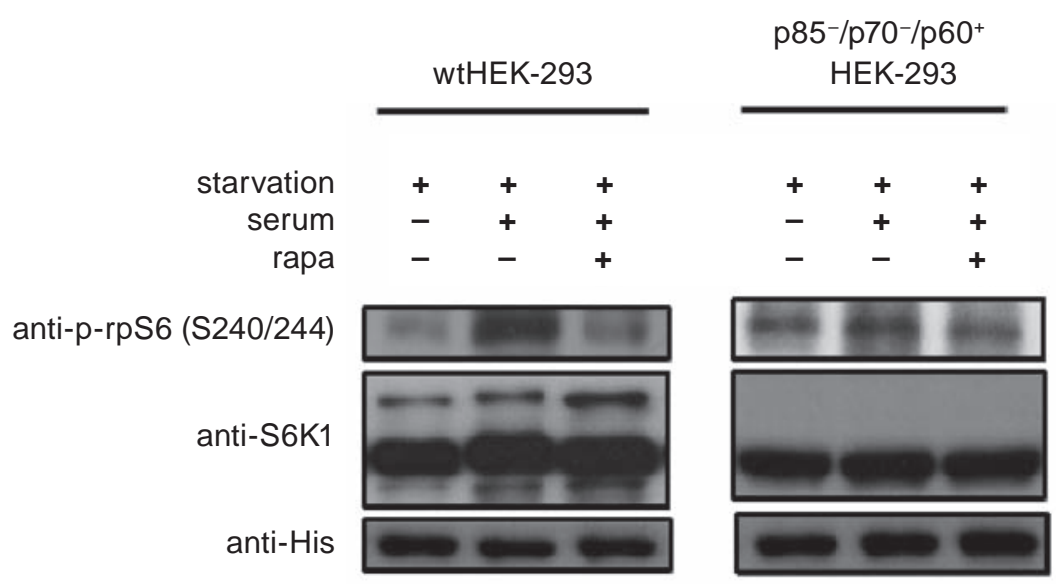

Fig. 4. Kinase activity of the p60-S6K1 isoform in HEK-293 cells is not dependent on mTORC1 activity. The indicated cell lines were deprived of serum for $24 \mathrm{~h}$, incubated in the presence or absence of either $20 \mathrm{nM}$ rapamycin (rapa) for $30 \mathrm{~min}$ and then stimulated with 20\% serum for $1 \mathrm{~h}$. S6K1 isoforms were extracted from the lysates by immunoprecipitation with anti-S6K1/C-terminus antibodies. Immunoprecipitated S6K1 and 6xHis-rpS6 as a substrate were used for the in vitro kinase assay that was analyzed by Western blot using anti-p-rpS6(S240/244) antibodies. The amount of S6K1 and His-rpS6 in the kinase reaction was monitored by Western blot analysis with anti-S6K1 and anti-His antibodies

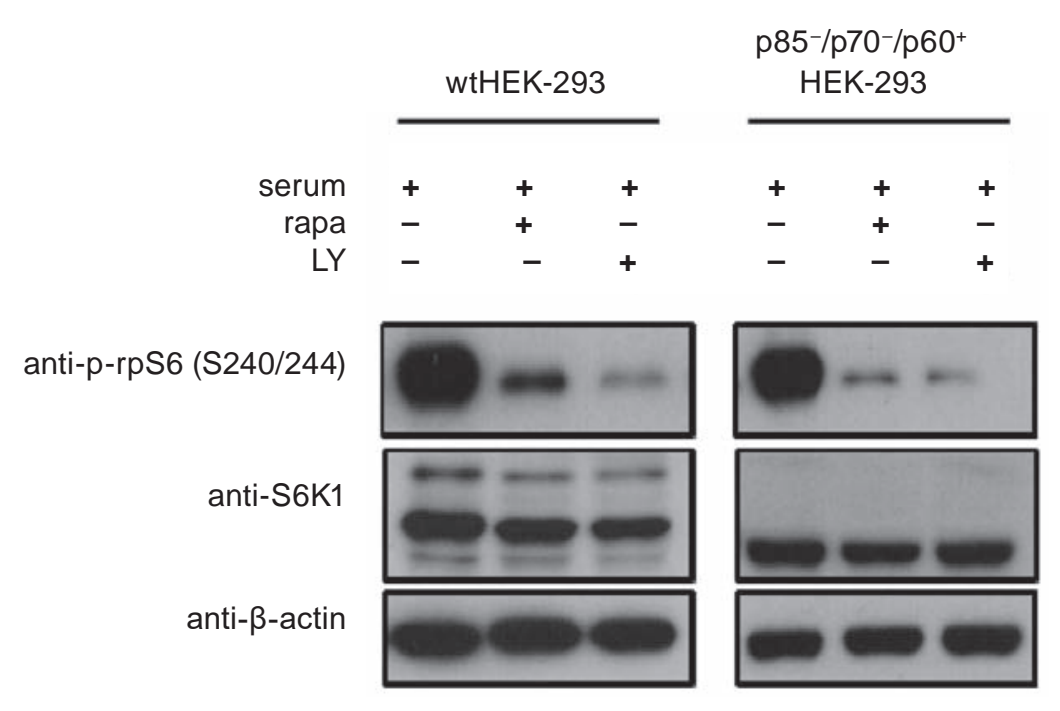

Fig. 5. HEK-293 cells with selective expression of p60-S6K1 exhibit similar extent of inhibition of rpS6 phosphorylation under the condition of treatment with PI3K/mTORC1-specific inhibitors as compared to wild-type HEK-293 cells. The cells were serum-starved for $24 \mathrm{~h}$, incubated in the presence or absence of either $20 \mathrm{nM}$ rapamycin (rapa) or $50 \mu \mathrm{M}$ LY294002 (LY) for 30 min followed by restimulation with 20\% serum for $1 \mathrm{~h}$. The cells were lysed and cell lysates were immunoblotted with the indicated antibodies

The data presented indicate that (i) p60-S6K1 represents a kinase active isoform phosphorylating in vitro its substrate ribosomal protein S6 and (ii) modulation of p60-S6K1 kinase activity via PI3K/ mTORC1 signaling depends on a cell type-specific context. Unlike MCF-7, the HEK-293 cells do not in- volve the PI3K/mTORC1 signaling pathway to exert their control on p60-S6K1 function. However, a precise mechanism of such control remains unknown and future research will be required to determine molecular steps which govern p60-S6K1 activity in HEK-293. 
Acknowledgements. This work was supported in part by the State Budget Program "Support for the Development of Priority Areas of Scientific Research" (Code: 6541230) and a fellowship from Boehringer Ingelheim Fonds (BIF) awarded to Igor Zaiets.

Conflict of interest. Authors have completed the Unified Conflicts of Interest form at http:// ukrbiochemjournal.org/wp-content/uploads/2018/12/ coi_disclosure.pdf and declare no conflict of interest.

\section{p60 Є НОВОЮ ІЗОФОРМОЮ S6 КІНАЗИ 1, ЯКА МАС КІНАЗНУ АКТИВНІСТЬ І ВІДРІЗНЯЕТЬСЯ ЗА СПОСОБОМ РЕГУЛЯЦІї ВІД р70 ТА p85 ІЗОФОРМ}

\section{I. В. Заєиьь, В. В. Голяр, А. С. Сівченко, \\ В. В. Смялковська, В. В. Філоненко}

Інститут молекулярної біології і генетики НАН України, Київ; e-mail: filonenko@imbg.org.ua

$\mathrm{PI} 3 \mathrm{~K} / \mathrm{mTORC1}$ сигнальний шлях залучений до контролю багатьох клітинних функцій, що регулюють фосфорилування одного зі своїх медіаторів - кінази 1 рибосомного протеїну S6 (S6K1). За рахунок альтернативної трансляції загального S6K1 транскрипту може відбуватися продукція трьох ізоформ, зокрема p85-S6K1, p70-S6K1 та p60-S6K1. Каталітична активність S6K1 модулюється мітогенами та ростовими факторами шляхом фосфорилування за трьома критичними сайтами, такими як активаційна петля (Т-loop сайт), мотив повороту (ТМ сайт) та гідрофобний мотив (НМ сайт). Обидва компоненти PI3K/mTORC1 шляху, PDK1 та mTORC1, напряму фосфорилюють відповідно T-loop та НМ сайти. Проте більшість досліджень, які спрямовано на вивчення регуляції S6K1, було направлено на p70- та p85-S6K1, у той час як вивченню активності і регуляції p60-S6K1 не було приділено уваги. Для того, щоб перевірити чи володіс p60-S6K1 кіназною активністю і регулюється подібно до p70/p85-S6K1, було використано попередньо створені нами клітини $\mathrm{p} 85 \%$ p70/p60+HEK-293. Спочатку in vitro кіназний тест підтвердив здатність p60-S6K1 фосфорилувати рибосомний протеїн $\mathrm{S} 6$ (rpS6), відомий субстрат S6K1. Далі аналіз фосфорилування
p60-S6K1 за різних умов росту клітин показав відсутність фосфорилування p60-S6K1 за PDK1та mTORC1-регульованими сайтами, проте ця ізоформа була фосфорильована за ТM сайтом. Нарешті, ми з'ясували, що активність р60-S6K1 $\epsilon$ нечутливою до мітогенної стимуляції та обробки клітин потужними інгібіторами PI3K/ mTORC1-залежного сигнального шляху рапаміцином за наявності PI3K/mTORC1-незалежного механізму регуляції р60-S6K1 в HEK-293. За результатами дослідження можна припустити, що ізоформа p60-S6K1 виявляє власну кіназну активність, яка регулюється незалежно від PI3K/mTORC1 сигнального шляху в клітинах HEK-293. Більш того, модуляція активності р60S6K1 через PI3K/mTORC1 сигнальний шлях залежить, ймовірно, від типу клітини, оскільки ізоформа p60-S6K1 підлягає PDK1- та mTORC1опосередкованому фосфорилуванню в клітинній лінії раку молочної залози MCF-7.

К л ю ч о в і с л ов а: p60-S6 кіназа 1 (p60S6K1), PI3K/mTORC1 сигнальний шлях, кіназна активність, регуляція шляхом фосфорилування протеїну.

\section{References}

1. Magnuson B, Ekim B, Fingar DC. Regulation and function of ribosomal protein S6 kinase (S6K) within mTOR signalling networks. Biochem $J$. 2012; 441(1): 1-21.

2. Fenton TR, Gout IT. Functions and regulation of the 70kDa ribosomal S6 kinases. Int J Biochem Cell Biol. 2011; 43(1): 47-59.

3. Bahrami-B F, Ataie-Kachoie P, Pourgholami MH, Morris DL. p70 Ribosomal protein S6 kinase (Rps6kb1): an update. J Clin Pathol. 2014; 67(12): 1019-1025.

4. Dann SG, Selvaraj A, Thomas G. mTOR Complex1-S6K1 signaling: at the crossroads of obesity, diabetes and cancer. Trends Mol Med. 2007; 13(6): 252-259.

5. Kim D, Akcakanat A, Singh G, Sharma C, Meric-Bernstam F. Regulation and localization of ribosomal protein S6 kinase 1 isoforms. Growth Factors. 2009; 27(1): 12-21.

6. Zaiets IV, Sivchenko AS, Khoruzhenko AI, Savinska LO, Filonenko VV. The p60-S6K1 isoform of ribosomal protein S6 kinase 1 is a product of alternative mRNA translation. $U k r$ Biochem J. 2018; 90(4): 25-35. 
7. Mahalingam M, Templeton DJ. Constitutive activation of S6 kinase by deletion of aminoterminal autoinhibitory and rapamycin sensitivity domains. Mol Cell Biol. 1996; 16(1): 405-413.

8. Cheatham L, Monfar M, Chou MM, Blenis J. Structural and functional analysis of pp70S6k. Proc Natl Acad Sci USA. 1995; 92(25): 1169611700.

9. Savinska LO, Kijamova RG, Pogrebnoy PV, Ovcharenko GV, Gout IT, Filonenko VV. Comparative characterization of S6 kinase $\alpha$ and $\beta$ isoforms expression in mammalian tissues. Biopolym Cell. 2001; 17(5): 374-379.

10. Alessi DR, Kozlowski MT, Weng QP, Morrice N, Avruch J. 3-Phosphoinositide-dependent protein kinase 1 (PDK1) phosphorylates and activates the p70 S6 kinase in vivo and in vitro. Curr Biol. 1998; 8(2): 69-81.

11. Pullen N, Dennis PB, Andjelkovic M, Dufner A, Kozma SC, Hemmings BA, Thomas G. Phosphorylation and activation of p70s6k by PDK1. Science. 1998; 279(5351): 707-710.

12. Weng QP, Kozlowski M, Belham C, Zhang A, Comb MJ, Avruch J. Regulation of the p70 S6 kinase by phosphorylation in vivo. Analysis using site-specific anti-phosphopeptide antibodies. J Biol Chem. 1998; 273(26): 1662116629.

13. Williams MR, Arthur JS, Balendran A, van der Kaay J, Poli V, Cohen P, Alessi DR. The role of 3-phosphoinositide-dependent protein kinase 1 in activating AGC kinases defined in embryonic stem cells. Curr Biol. 2000; 10(8): 439-448.

14. Saitoh M, Pullen N, Brennan P, Cantrell D, Dennis PB, Thomas G. Regulation of an activated S6 kinase 1 variant reveals a novel mammalian target of rapamycin phosphorylation site. J Biol Chem. 2002; 277(22): 20104-20112.

15. Isotani $\mathrm{S}$, Hara $\mathrm{K}$, Tokunaga $\mathrm{C}$, Inoue $\mathrm{H}$, Avruch J, Yonezawa K. Immunopurified mammalian target of rapamycin phosphorylates and activates p70 S6 kinase alpha in vitro. J Biol Chem. 1999; 274(48):34493-34498.
16. Dennis PB, Pullen N, Pearson RB, Kozma SC, Thomas G. Phosphorylation sites in the autoinhibitory domain participate in p70(s6k) activation loop phosphorylation. $\mathrm{J}$ Biol Chem. 1998; 273(24): 14845-14852.

17. Schalm SS, Blenis J. Identification of a conserved motif required for mTOR signaling. Curr Biol. 2002; 12(8): 632-639.

18. Moser BA, Dennis PB, Pullen N, Pearson RB, Williamson NA, Wettenhall RE, Kozma SC, Thomas G. Dual requirement for a newly identified phosphorylation site in p70s6k. Mol Cell Biol. 1997; 17(9): 5648-5655.

19. Mukhopadhyay NK, Price DJ, Kyriakis JM, Pelech S, Sanghera J, Avruch J. An array of insulin-activated, proline-directed serine/ threonine protein kinases phosphorylate the p70 S6 kinase. J Biol Chem. 1992; 267(5): 3325-3335.

20. Ferrari S, Bannwarth W, Morley SJ, Totty NF, Thomas G. Activation of p70s6k is associated with phosphorylation of four clustered sites displaying Ser/Thr-Pro motifs. Proc Natl Acad Sci USA. 1992; 89(15): 7282-7286.

21. Banerjee P, Ahmad MF, Grove JR, Kozlosky C, Price DJ, Avruch J. Molecular structure of a major insulin/mitogen-activated $70-\mathrm{kDa}$ S6 protein kinase. Proc Natl Acad Sci USA. 1990; 87(21): 8550-8554.

22. Price DJ, Mukhopadhyay NK, Avruch J. Insulin-activated protein kinases phosphorylate a pseudosubstrate synthetic peptide inhibitor of the p70 S6 kinase. J Biol Chem. 1991; 266(25): 16281-16284.

23. Han JW, Pearson RB, Dennis PB, Thomas G. Rapamycin, wortmannin, and the methylxanthine SQ20006 inactivate p70s6k by inducing dephosphorylation of the same subset of sites. J Biol Chem. 1995; 270(36): 2139621403.

24. Ferrari S, Pearson RB, Siegmann M, Kozma SC, Thomas G. The immunosuppressant rapamycin induces inactivation of p70s6k through dephosphorylation of a novel set of sites. $J$ Biol Chem. 1993; 268(22): 16091-16094. 